Original Research Paper

\title{
Comparative Characteristic of two Cultivars of Winter Common Wheat (Triticum Aestivum L.) Cultivated in the Southeast of Kazakhstan using the Drip Irrigation Technology
}

\author{
${ }^{1}$ Zhanar Muratovna Yeraliyeva, ${ }^{2}$ Meruyert Sakenovna Kurmanbayeva, \\ ${ }^{3}$ Karina Khamidovna Makhmudova, ${ }^{4}$ Tanko Peev Kolev and ${ }^{5}$ Serik Muktarovich Kenesbayev \\ ${ }^{1}$ Kazakh State Women's Teacher Training University, Kazakhstan, Almaty, 050000, 99 Aiteke bi Str, Kazakhstan \\ ${ }^{2}$ Al-Farabi Kazakh National University, Kazakhstan, Almaty, 050040, 71 al-Farabi Ave, Kazakhstan \\ ${ }^{3}$ Kazakh State Women's Teacher Training University, Kazakhstan, Almaty, 050000, 99 Aiteke bi Str, Kazakhstan \\ ${ }^{4}$ Agricultural University, Bulgaria, Plovdiv, 4000, 12 "Mendeleev" Blvd, Bulgaria \\ 5Director of Branch of JSC "NCPD "ORLEU” Institute for Professional Development of Almaty City, \\ Kazakhstan, Almaty, 050019, 50 Kabilov Str, Kazakhstan
}

Article history

Received: 09-02-2017

Revised: 06-05-2017

Accepted: 30-05-2017

Corresponding Author:

Karina Khamidovna

Makhmudova

Kazakh State Women's Teacher

Training University, Kazakhstan,

Almaty, 050000, 99 Aiteke bi

Str, Kazakhstan

E-mail:

carinamakhmudova2015@gmail.com

\section{Introduction}

It is known that one of the most important and ancient crop in the world agriculture is wheat. Common wheat (Triticum aestivum L.) is the important cereal and widely adapted crop that provides inquiries in grain of
Abstract: The purpose of our research was studying the indicators of grain quality, productivity and analysis of anatomical stem structure during the full maturity of two cultivars of winter common wheat. Novelty of work consists in carrying out such a research using a local standard cultivar Almaly and a new cultivar SWW 2/127 grown using the drip irrigation technology. Researches were carried out in field and laboratory conditions using methods of field experiment, drip irrigation, microscopic section and biometric analysis. Stem structure of the 3rd internode, epidermis thickness, length and width of large conducting bundles, xylem length and width, thickness of parenchyma cell and culm thickness were analyzed. SWW $2 / 127$ cultivar demonstrated increase of the values of these traits. Other biometric indicators of SWW 2/127 cultivar such as thickness of mechanical tissue and bark, length and width of small conducting bundles demonstrated their decreasing in comparison with Almaly cultivar. Some increasing of the total quantity of small conducting bundles of the primary bark of Almaly cultivar was noted in comparison with SWW 2/127 cultivar; and vice versa decreasing of the total quantity of large conducting bundles of Almaly cultivar was observed in comparison with SWW 2/127 cultivar. Almaly cultivar had higher rates of mass of 1000 grains $(51.7 \mathrm{~g})$, grain nature $\left(772 \mathrm{~g} \mathrm{~L}^{-1}\right)$, glassiness $(85 \%)$, protein quantity $(15.6 \%)$ and gluten quantity $(34.4 \%)$. Both cultivars formed grain nature, glassiness, starch and protein quantity, gluten quantity at the level of State standards for strong and valuable wheat; gluten quality corresponded to the 2nd group. Indicators of the ear structure of Almaly cultivar were higher than indicators of SWW 2/127 cultivar. Productivity of Almaly cultivar was 91.8 centners per a hectare, seed sowing norm was 2 million grains per a hectare; productivity of SWW 2/127 cultivar at the same norm of seed sowing was 77.4 centners per a hectare.

Keywords: Winter Common Wheat, Drip Irrigation, Anatomical Structure, Grain Quality, Productivity

one third of the world (Rajaram, 2001). Common wheat (Triticum aestivum L., $2 \mathrm{n}=6 \times=42$ ) is a main species that is worldwide cultivated covering more than $85 \%$ of the agricultural area. Wheat is also a food crop which is most widely cultivated in the world. Food and Agricultural Service (FAS) of the U.S. Department of Agriculture 
(2005). Wheat (Triticum spp.) is also the most important grain culture in the world from the point of view of production. In 2009, wheat world production was 685.61 million tons; the second place belongs to rice. In 2009, rice world production was 685.24 million tons (FAO, 2011). Production of wheat grain in many regions of the world is not sufficient for the needs of increasing population (El-Maghraby et al., 2005). So, in a number of researches the great gap between production and consumption of wheat was revealed. The harvest and quality of grain of winter wheat are defined by soilclimatic conditions and science-based technologies of cultivation; their main elements are cultivars, predecessors, mineral nutrition, terms of sowing and norm of seeding (Martre et al., 2003). One of the most key problems of wheat cultivation is deficiency of water. The water stress influences growth, physiological processes and productivity of wheat (Metwaly, 2012). The drought as a stressful factor causes changes in physiological processes and reduces ability of the biosynthesis and, perhaps, causes some destructive damages of a plant (Lichtenthaler, 1996).

Plants in severe conditions of water deficiency caused by drought cease growing and accumulate completely dissolved substances in cells for maintenance of cellular volume and turgor. One can reveal plant dehydration, i.e., osmotic regulation which is disrupted in stems, leaves and roots (Nonami, 1998; Patakas et al., 2002). In conditions of water stress in wheat during its vegetative growth phyllochron decreases (Mcmaster, 1997); and leaves become smaller in size that can decrease the indicators of the leaf area and the number of reproductive shoots, in addition it restricts their contribution to grain yield (Gupta et al., 2001; Dencic et al., 2000). During the decades demand for water considerably rose due to the climate change, constant drought and increase of water requirements connected with increase of the irrigated surfaces and urbanization. In the system of actions for rationalization and enhancement of productivity potential the essential value belongs to technologies and methods of irrigation which provide possibility of supply of irrigation water and nutrients directly to the zone of root nutrition of plants. The drip irrigation technology belongs to such methods of watering (Ovchinnikov and Akulinina, 2010). The numerous researches mainly carried out abroad showed that the most efficient way of rational use of irrigation water is drip irrigation of crops. Drip irrigation is such a method of watering when water in small portions is regularly supplied to plant roots throughout the vegetative period and irrigational moisture is delivered to plants without wasting in row-spacing. Thanks to it the system of drip irrigation is more effective method than other methods of irrigation (Tiwari et al., 2003; Paul et al., 2013; Seyfi and Rashidi, 2007; Phene, 1995; Yeraliyeva et al., 2016).
In the letter of President of the Republic of Kazakhstan Nazarbayev (2014) to the people of Kazakhstan "The Kazakhstan way-2050: United aim, united interests, united future" special attention was paid to development of agro-industrial complex and to the transition to innovative rails. It was noted that the global need for food would increase. Therefore, modern farmers should care for increase in production but should not be satisfied only with the short achievements connected with weather conditions. First of all only the farmers implementing new technologies, continuously increasing productivity and using the best main international standards should cultivate the land (Nazarbayev, 2014).

The drip irrigation is successfully used in case of cultivation of a wide range of various crops, in particular vegetables, garden cultures, flowers and plantation crops. However, for grain crops, in particular for wheat, the limited researches to study this method were carried out. In a number of researches, it was revealed that to produce 1 kilo of wheat grain one should use about 1000 liters of irrigation water. Application of the drip irrigation technology saves up to $20 \%$ of irrigation water in comparison with surface irrigation (Kharrou et al., 2011; Hoff, 2004). Success of use of drip irrigation is determined by a complex of factors (soil type, climatic conditions and ability to regulate the irrigation system) and, therefore, the technology should be checked and adapted to specific conditions of cultivation of a certain crop. One will not find a great number of the researches for checking the possibility of use of the alternative drip irrigating systems (surface and underground) in the intensive field conditions (Abdelraouf et al., 2013; Arafa et al., 2009; Alam et al., 2009; Suarez-Rey et al., 2000; Abd El-Rahman, 2009; Camp, 1998). Researchers carried out the assessment of suitability of lands for two types of irrigation, i.e., surface watering and drip irrigation. According to this investigation, drip irrigation more corresponds to the irrigated lands in comparison with surface irrigation. Surface irrigation in assessment of its suitability clashed with the topographical slopes, depth and texture of the soil and limitation of drainage (Albaji et al., 2014).

The purpose of our research was comparative studying the indicators of grain quality, productivity and analysis of biometric indicators of anatomical structure of the stem during the full maturity of winter common wheat of the local standard cultivar Almaly and a new cultivar of the super wheat SWW 2/127 grown using the technology of drip irrigation. In Kazakhstan the drip irrigation technology is not enough studied and not developed completely. In this connection, our researches were carried in the foothill of the Ile Alatau in the irrigated zone, on light-chestnut soils of the southeast of Kazakhstan for studying the efficiency of drip irrigation of winter common wheat. 


\section{Materials and Methods}

Two cultivars of winter common wheat were chosen (Triticum aestivum L.) as objects of researches: A competitive, zoned, standard cultivar of domestic selection Almaly (further Almaly) and a new cultivar of super wheat SWW 2/127 (further SWW 2/127). Almaly, a cultivar of winter common wheat was bred in LLP "Kazakh research institute of agriculture and plant growing". It was created by method of intra specific hybridization: (K-50431×Bezostaya-1) with the subsequent individual selection. K-50431, the sample from Bulgaria, Bezostaya-1, the sample from the USSR (the source is All-Russian Institute of Plant Industry). Its variety is nigri-erythrospermum. The cultivar is mid-ripening, its ear emergence and ripening come 2-3 days later in comparison with standard cultivar Zhetysu. Weight of 1,000 grains is 47-54 g. Its winter hardiness is higher than average, drought resistance is high; lodging resistance is $8-9$ points. Height of a stem is $80-110 \mathrm{~cm}$ (Zhangaziyev, 2010). It differs in high plasticity and complex resistance to brown rust (Puccinia triticina), yellow rust (Puccinia glumarum) and leaf blotch (Septoria nodorum). Its potential productivity is 65-70 centners per a hectare. According to grain quality this cultivar belongs to valuable wheat. The author' certificate No 134, June 24, 2002. Since 2003, it was allowed to cultivation in Almaty, Zhambyl and Southern Kazakhstan areas of the Republic of Kazakhstan. By results of the state trial (1999-2003) Almaly cultivar in 17 trial plots among 19 surpassed in productivity of grain the earlier zoned cultivars (Bezostaya-1, Zhetysu, Odesskaya-120, Yuzhnaya-12 and Krasnovodopadskaya210) from 2 up to 20 centners per a hectare. According to statistical data of the Republic of Kazakhstan of 2008, this cultivar occupied 7.6 thousand hectares. Almaly cultivar gives the guaranteed harvest increase from 2 to 6 centners per a hectare; on average is 0.4 tons per a hectare. Extra production of this cultivar in its zoned area composes 120 thousand tons annually (300 thousand hectares $\times 0.4$ tons per a hectare). The authors are Urazaliyev R.A., Zhangaziyev A.S., Kalibayev B.S. and Gabdullin K.M.

Experiment was carried out in the field and laboratory conditions. The field experiment was carried out in the irrigated zone of the Ile Alatau foothill (2014-2015) at the demonstration site "Ushkonyr" of LLP "Kazakh Research Institute of Agriculture and Plant Growing" on light-chestnut soils. The total area of the experiment site was 0.10 hectare. The area of the plots was 50 sq. $\mathrm{m}$ in triple replication.

According to Table 1: The content of humus in 0-30 $\mathrm{cm}$ 's layer of the soil of the experimental site was $2.06 \%$; total nitrogen was $0.14 \%$; gross phosphorus was $0.07 \%$.
According to the content of mobile nutrition elements the soil was characterized as having very low content of mobile phosphorus, low content of mobile alkali hydrolized nitrogen and high content of exchange potassium. In the present work the following techniques of researches of soils were used (Kaurichev, 1973; Frolova and Atselovich, 1965): Determination of total humus; determination of alkali nitrogen; determination of nitric nitrogen; determination of exchange potassium and mobile phosphorus. Phenological observations were carried out according to the phases of development of plants. During the anatomical researches measurement of the biometric indicators was carried out by the standard methods. Fixation of over ground and underground parts of plants was carried out in the preserving mixture alcohol-glycerin-water (1:1:1) (Permyakov, 1988). Temporary anatomical specimens were done manually with use of the blade of the ordinary razor. The slices in 10-15 microns thickness were kept in glycerin (Prozina, 1960). The prepared temporary specimens were used for making the microphotography and carrying out the morphometric analysis using the microscope Micros Austria MCX100 with the video camera 519CU 5.OM CMOS (lens $10 \times / 0.25$, magnification $100 \times$ ). Statistical processing of morphometric indicators was done via standard methods (Lakin, 1990).

The analysis of grain quality was carried out in the laboratory of technological evaluation of grain of the LLP "Kazakh Research Institute of Agriculture and Plant Growing". The indicators of grain quality were found by the methods presented in the State Standards (GOST, 2017a; 2017b; 2017c; 2017d; 2017e; 2017f; 2017g): Mass of 1,000 grains; grain nature; glassiness; humidity of grain; quantity of protein; quantity of starch; quantity and quality of gluten. Statistical processing of harvest data was carried out by via standard methods (GOST, 2017f). Before cropping the experimental samples of two cultivars were selected for definition of basic elements of the harvest structure. Harvesting the wheat from the experimental sites was carried out by the mono-phase combine "SAMPO-250" (Fig. 1).

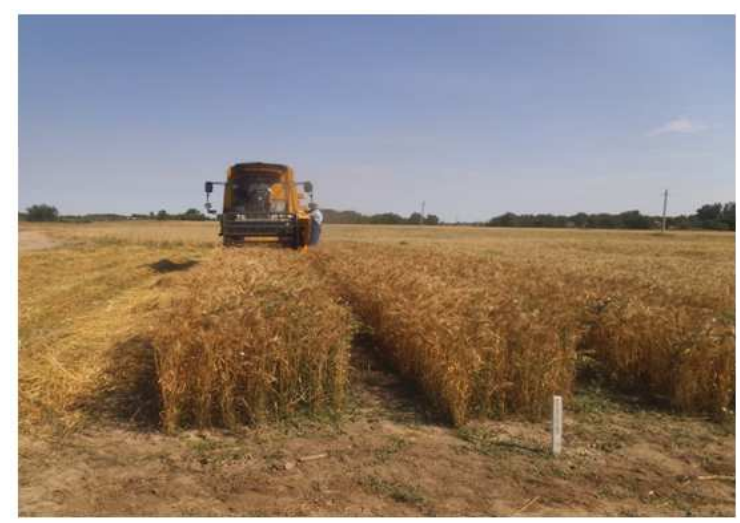

Fig. 1. Harvesting the cultivars of winter common wheat Almaly and SWW 2/127 
Table 1. Agrochemical characteristic of the experimental site Indicators

\begin{tabular}{|c|c|c|c|c|c|c|c|}
\hline \multirow[b]{2}{*}{ Soil type } & \multicolumn{4}{|l|}{$\%$} & \multicolumn{3}{|l|}{$\mathrm{mg} / \mathrm{kg}$ of soil } \\
\hline & Layer $(\mathrm{cm})$ & Humus & Total nitrogen & $\begin{array}{l}\text { Gross } \\
\text { phosphorus }\end{array}$ & $\begin{array}{l}\text { Alkali hydrolized } \\
\text { nitrogen }\end{array}$ & $\begin{array}{l}\text { Mobile } \\
\text { phosphorus }\end{array}$ & $\begin{array}{l}\text { Exchange } \\
\text { potassium }\end{array}$ \\
\hline Light-chestnut & $0-30$ & 2.06 & 0.14 & 0.07 & 155 & 11,9 & 427 \\
\hline
\end{tabular}

\section{Results}

It is known that the stem of wheat is characterized by primary anatomical structure. It has the plump peripheral part and a cavity lacuna in the center. A peripheral part is formed by the epidermis which is poor notable against the background of a sclerenchyma, the primary bark and the central cylinder. The central cylinder consists of the closed conducting bundles, the ring of the mechanical tissue (sclerenchyma) and the storage parenchyma (Lazarevich, 1999). The epidermis consists of the identical cells located densely in one chain and on the surface of the external epidermis the cuticle is formed. The sclerenchyma cells forming the mechanical tissue adjoin to the epidermis. The mechanical tissue consists of the small cells with a thick cell wall which tightly adjoin to each other and are arranged in several rows. Behind the mechanical tissue the colourless parenchyma is located. The parenchyma is formed by multi-scale large cells with a thin cytoderm (cell wall). There is no parenchyma in the centre and the lacuna is formed. Conducting bundles are divided into large and small ones. Small conducting bundles are located in the mechanical tissue distantly from each other. They provide metabolism in the cells of the primary bark. In the main tissue closer to the center there are large conducting bundles, they form the regular circle. All conducting bundles are collateral and closed. The metaxylem is presented by two large porous vessels; among these vessels a small number of the fibrous tracheids are located.

In the present research for the chosen cultivars grown with application of the drip irrigation technology we carried out the comparative analysis of the biometric indicators. Also the features of the anatomical structure of the stem (Fig. 2) on the site of the transversal slice of the third internode during the complete maturity of grain were determined.

Anatomical structure of the stem of the studied cultivars of winter common wheat grown with use of drip irrigation technology. As it is visible on the transversal slice the phloem is presented in the form of a sieve tube. Conducting bundles have the facing composed of sclerenchyma; the strength of the mechanical facing depends on the volume of bundles, arrangement in the stem and the internodes. In the stem the number of conducting bundles changes. In sclerenchyma their number is less than in the inside part. In the middle part of the stem the core is not kept.
Solid stems of common wheat (Triticum aestivum L.) are thin but very rigid; the stem is filled with solid suber. The stems of common wheat are assumed to be resistant to lodging thanks to their morphological features and stem durability. It is known that stem strength of cultural plants, presence of a solid core interferes with larval growth and movement of larvae and, in particular, promotes the increased resistance to damage of the saw-fly larvae (Cephus pygmaeus) (Wallace et al., 1966).

As a result of growth of cells and stem thickening the core of a stem is torn and the lacuna, the feature of many cereals, is formed. That stem is called a culm. It was noticed that the new cultivar of super wheat SWW 2/127 differed from the standard cultivar Almaly, its stem was higher (Fig. 3). The stem height of Almaly cultivar was $110 \mathrm{~cm}$, the stem height of SWW 2/127 cultivar was $120 \mathrm{~cm}$.

The results of measurement of biometric indicators of the anatomical structure of a stem of the studied cultivars are presented in Table 2.

According to Table 2 the analysis of the quantitative data of biometric indicators demonstrated the following: The thickness of epidermis of Almaly cultivar was smaller than the same of SWW 2/127 cultivar, 39.16 and 41.45 microns, respectively; the thickness of mechanical tissue of Almaly was bigger than the same of SWW 2/127 cultivar, 237.31 and 224.23 microns, respectively; the thickness of primary bark of Almaly cultivar was bigger than the same of SWW 2/127 cultivar, 608.87 and 468.27 microns, respectively; the length of a small conducting bundle of Almaly cultivar was bigger than the same of SWW 2/127 cultivar, 246.7 and 142.2, respectively; the width of a small conducting bundle of Almaly was bigger than the same of SWW 2/127 cultivar, 292.3 and 233.6 microns, respectively; the length of large conducting bundle of Almaly was smaller than the same of SWW 2/127 cultivar, 563.4 and 617.8 microns, respectively; the width of large conducting bundle of Almaly was smaller than the same of SWW 2/127 cultivar, 511.8 and 522.5 microns, respectively; the length of xylem of Almaly was smaller than the same of SWW 2/127 cultivar, 146.1 and 159.5 microns, respectively; the width of xylem of Almaly was smaller than the same of SWW 2/127 cultivar, 139.6 and 147.2 microns, respectively; the thickness of parenchyma cell of Almaly was smaller than the same of SWW 2/127 cultivar, 399.7 and 410.1 microns respectively; the thickness of a stem of Almaly was smaller than the same of SWW 2/127 cultivar, 2089.1 and 2335.7 microns, respectively. 

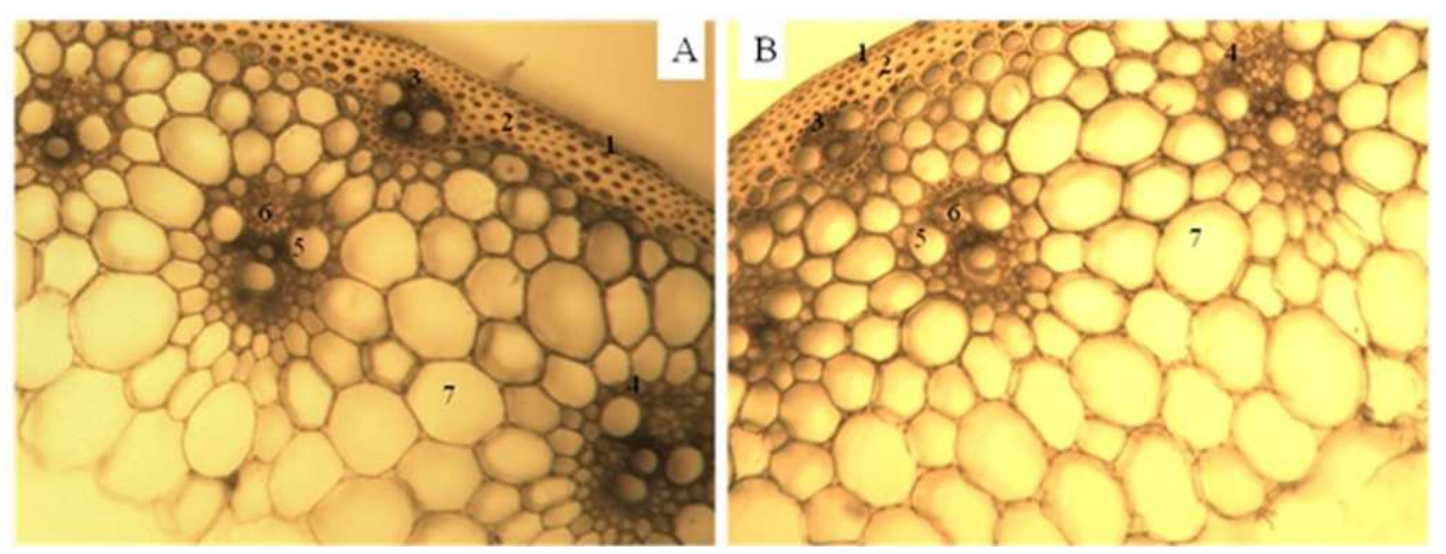

Fig. 2. The site of the transversal slice of the 3rd over ground internode of the cultivars of winter common wheat A- Almaly cultivar, B- SWW 2/127 cultivar: 1-Epidermis; 2-Mechanical tissue; 3-Small conducting bundle; 4-Large conducting bundle; 5Xylem; 6-Phloem; 7-Parenchyma, 100×Magnification


Fig. 3. Winter common wheat in the phase of full maturity, Ushkonyr. Almaly cultivar is on the left; SWW 2/127 cultivar is on the right

Table 2. Biometric indicators of the anatomical structure of the stem (3rd internode) in the studied cultivars The cultivars of winter common wheat

\begin{tabular}{|c|c|c|c|}
\hline \multirow[b]{2}{*}{ Biometric indicators, microns } & & \\
\hline & & Almaly & SWW 2/127 \\
\hline Epidermis thickness & & $39.16 \pm 3.79$ & $41.45 \pm 4.43$ \\
\hline Mechanical tissue thickness & & $237.31 \pm 3.39$ & $224.23 \pm 0.91$ \\
\hline Primary bark thickness & & $608.87 \pm 1.57$ & $468.27 \pm 2.55$ \\
\hline \multirow[t]{2}{*}{ Small conducting bundle } & length & $246.70 \pm 1.17$ & $142.22 \pm 3.57$ \\
\hline & width & $292.29 \pm 5.63$ & $233.61 \pm 4.40$ \\
\hline \multirow[t]{2}{*}{ Large conducting bundle } & length & $563.43 \pm 3.18$ & $617.80 \pm 1.19$ \\
\hline & width & $511.79 \pm 5.19$ & $522.50 \pm 2.42$ \\
\hline \multirow[t]{2}{*}{ Xylem } & length & $146.06 \pm 4.09$ & $159.49 \pm 4.11$ \\
\hline & width & $139.63 \pm 4.67$ & $147.26 \pm 2.42$ \\
\hline Parenchymal cell thickness & & $399.74 \pm 3.43$ & $410.16 \pm 5.22$ \\
\hline Stem thickness & & $2089.14 \pm 3.61$ & $2335.70 \pm 1.50$ \\
\hline
\end{tabular}

It is known that thickness of sclerenchyma, the thickness of epidermis and the density of epidermis are the important factors for digestion of wheat straw as forage for ruminant animals (Travis et al., 1996). Cultivars which are less susceptible to lodging contain smaller amount of the neutral acquired fiber and, thus, have smaller nutritional value as forage for animals.

When studying the anatomical structure of a stem on the site of the third internode with video micro scope the studied cultivars demonstrated the ring of 
the mechanical tissue and inside of this ring there were small conducting bundles surrounding the stem. Larger conducting bundles with well developed xylem and phloem were located in the thickness of the main parenchyma. When comparing the total amount of small and large conducting bundles of two cultivars it was noted that the standard cultivar Almaly had 19 small conducting bundles of the primary bark and the cultivar SWW 2/127 had 14 small conducting bundles of the primary bark and vice versa the total amount of large conducting bundles of SWW 2/127 cultivar was more than the same of Almaly cultivar, 37 and 33, respectively.

Batoyev (1991) noted that well developed conducting system of a stem provides formation of well-grained ears; the more the total area of conducting system the bigger the mass of an ear and the mass of grain per an ear.

Grain quality. During our research the quality indicators of grain of the studied cultivars of winter common wheat Almaly and SWW 2/127 were determined, such as: Nature of grain $(\mathrm{g} / \mathrm{l})$, glassiness (\%), humidity, starch, protein, gluten quantity (\%) and gluten quality (Table 3 ). The studied cultivars of winter common wheat differed from each other by qualitative characteristics of grain.

As it was shown in Table 3, the indicator of grain nature of Almaly exceeded the same indicator of SWW 2/127 cultivar, $772 \mathrm{~g} \mathrm{~L}^{-1}$ and $748 \mathrm{~g} \mathrm{~L}^{-1}$, respectively; the glassiness indicator of Almaly cultivar exceeded the same one of SWW 2/127 cultivar, 85 and $63 \%$, respectively; the indicators of grain humidity of both cultivars were almost identical, 9.7 and $9.5 \%$, respectively; the starch quantity in grain of SWW 2/127 cultivar was a little bit higher than in grain of Almaly cultivar, 58.6 and $56.1 \%$, respectively; the protein quantity in grain of Almaly cultivar exceeded the protein quantity in grain of SWW 2/127 cultivar, 15.6 and $13.2 \%$, respectively; the gluten quantity in grain of Almaly exceeded the gluten quantity in grain of SWW 2/127 cultivar, 34.4 and $28 \%$, respectively. The gluten quality remained the same in both cultivars. It was 100 units of MGD. Almaly cultivar was also characterized with the highest grain nature $\left(772 \mathrm{~g} \mathrm{~L}^{-1}\right)$, the SWW 2/127 cultivar was characterized with the least grain nature $\left(748 \mathrm{~g} \mathrm{~L}^{-1}\right)$. The grain glassiness (the endosperm consistence) is considered one of the important indicators of wheat quality and its flourgrinding properties. The grain glassiness is one of the indicator according to which the consignment of grain belongs to this or that class during raw material purchase. This trait depends on cultivation conditions (level of mineral nutrition of plants). The glassiness influences the physical properties of grain, its flour- grinding, baking and commercial qualities. According to our research Almaly cultivar was characterized with the highest glassiness of grain, $85 \%$. The glassiness of grain of SWW 2/127 cultivar was $63 \%$.

Low humidity of grain causes an inactive condition of the microorganisms living on the grain. In such state they do not cause any changes in the grain during storage. Therefore the grain possessing the humidity $13.5-15.5 \%$ (Zharikova, 2005) is allowed to storage. The grain humidity of Almaly cultivar was $9.7 \%$; the grain humidity of SWW 2/127 cultivar was $9.5 \%$.

According to literary data, grain of winter wheat contains on average 54\% of starch (Kazakov and Karpilenko, 2005). The starch quantity of Almaly was less than starch quantity of SWW2/127, 56.1\% and $58.6 \%$, respectively.

Protein quantity is the most important indicator of technological and nutrition value of grain. According to literary data (Koehler and Wieser, 2013) the average amount of protein in grain of winter common wheat is $11.2 \%$. Protein in wheat grain is controlled by State Standard where one can find the following requirements: For the first class it must not be less $14.5 \%$; for the $2^{\text {nd }}$ class it must not be less $13.5 \%$; for the 3 rd class it must not be less $12 \%$; for the 4 th class it must not be less $10 \%$; for the 5 th class the size of this indicator is not limited. At the comparative analysis the largest protein quantity was determined in Almaly cultivar, 15.6\%. The slight decrease in size of this indicator was determined in SWW 2/127 cultivar, 13.2\%.

Gluten is a complex of the protein matters of grain capable at swelling in water to form coherent elastic mass. The gluten in grain and in flour in a large extent defines the exit and quality of cereal products. Active State Standard of the Republic of Kazakhstan 1046-2008 "Wheat. Technical specifications" requires: The gluten level for the highest class is to be not less than $32 \%$, for the first class is to be $28 \%$, for the second class is to be $25 \%$; for the third class is to be $23 \%$; for the fourth class is to be $18 \%$; for the fifth class the size of this indicator is not limited. When comparing two cultivars it was noted that SWW 2/127 cultivar concedes to Almaly cultivar by the gluten quantity, 28 and $34.4 \%$, respectively.

The structure analysis of an ear and productivity. The grain yield of cereals was defined by the number of productive ears, by the number of grains per an ear and by the mass of 1,000 grains (Dospekhov, 1985). Set of these indicators allowed defining the harvest structure, i.e., it was possible to determine what parameter or the set of parameters influenced the harvest increasing. When carrying out the comparative structure analysis of an ear of the studied cultivars it was noticed that the samples of the cultivars SWW 2/127 and Almaly were characterized by a variety (Table 4 ). 
Table 3. Quality indicators of grain of the studied cultivars of winter common wheat, 2016

\begin{tabular}{llllllll}
\hline Cultivar & $\begin{array}{l}\text { Grain } \\
\text { nature }(\mathrm{g} / \mathrm{l})\end{array}$ & $\begin{array}{l}\text { Glassiness } \\
\mathbf{( \% )}\end{array}$ & $\begin{array}{l}\text { Humidity } \\
(\mathbf{\%})\end{array}$ & $\begin{array}{l}\text { Starch } \\
(\mathbf{\%})\end{array}$ & $\begin{array}{l}\text { Protein } \\
(\mathbf{\%})\end{array}$ & $\begin{array}{l}\text { Gluten } \\
\text { quantity (\%) }\end{array}$ & $\begin{array}{l}\text { Gluten quality } \\
(\text { units of MGD) }\end{array}$ \\
\hline Almaly & 772 & 85 & 9.7 & 56.1 & 15.6 & 34.4 & 100 \\
SWW2/127 & 748 & 63 & 9.5 & 58.6 & 13.2 & 28 & 100 \\
\hline
\end{tabular}

Notes: MDG, measure of gluten deformation

Table 4. Comparative structure analysis of two studied cultivars of winter common wheat, 2016

\begin{tabular}{llllll}
\hline & & Number, pieces & & Mass, $\mathrm{g}$ \\
Cultivars & Stem length $(\mathrm{cm})$ & Spikelets & Grains per an ear & Grain per an ear & 1,000 Grains \\
\hline Almaly & 8.8 & 34 & 37 & 1.88 & 51.7 \\
SWW 2/127 & 7.3 & 30 & 34 & 1.26 & 42.2 \\
\hline
\end{tabular}

Table 5. Productivity of the studied cultivars of winter common wheat at drip irrigation, centners per a hectare, 2016 Norm of seed sowing, mln grains per a hectare

\begin{tabular}{|c|c|c|c|}
\hline \multirow[b]{2}{*}{ Cultivars } & & & \\
\hline & 2.0 & 4 & 6.0 \\
\hline Almaly & 91.8 & 101 & 98.8 \\
\hline $\begin{array}{l}\text { SWW 2/127 } \\
\mathrm{P}=3.1 \%, \mathrm{LE}\end{array}$ & 77.4 & 93 & 93.0 \\
\hline
\end{tabular}

$\mathrm{P}=3.1 \%, \mathrm{LED}_{0.95}=6,2$ centners per a hectare

Analyzing data of Table 4 it is possible to note that the greatest length of an ear appeared at the standard cultivar Almaly. It was $8.8 \mathrm{~cm}$. It was about $1.5 \mathrm{~cm}$ more than at the cultivar SWW 2/127. By the number of spikelets and number of grains per an ear the domestic standard cultivar Almaly demonstrated high indicators: 34 spikelets and 37 grains, respectively. In the experiment the biggest mass of grain per an ear was formed by the standard cultivar Almaly and the least mass was formed by the cultivar SWW 2/127: $1.88 \mathrm{~g}$ and $1.26 \mathrm{~g}$, respectively. One of the most important indicators of physical properties of wheat grain is the mass of 1,000 grains. The high rate of this trait indicates the large supply of nutrients in grain; this rate depends on the cultivar, conditions of cultivation, duration of the phase of grain filling and can vary from 20 to $60 \mathrm{~g}$. The standard cultivar Almaly showed steadily high indicators. Its mass of 1,000 grains was $51.7 \mathrm{~g}$. It should be noted that the mass of 1,000 grains of the cultivar SWW 2/127 was also good, it was $42.2 \mathrm{~g}$. The data of grain yield of the studied cultivars of winter common wheat grown when using the drip irrigation technology are presented in Table 5. Almaly cultivar demonstrate the best productivity than SWW2/127, $91.8 \mathrm{c} / \mathrm{he}$ and $77.4 \mathrm{c} / \mathrm{he}$, respectively.

\section{Discussion}

Grain of wheat is an organic product; its quality is characterized by a complex of properties. One can distinguish physical, physiological, biochemical and technological properties. One of the main physical traits of grain quality is natural weight of grain. Grain nature is also one of the traits which are the cornerstone of wheat grain classification in all countries. It is very changeable indicator and it depends on the cultivar and cultivation conditions. According to active SSRK (2017) there were established requirements for grain nature size. At comparative research of two cultivars of winter common wheat there were determined that the indicators of grain nature of Almaly mostly exceeded the same indicator of SWW 2/127 cultivar. For the highest class the grain nature must not be less than $760 \mathrm{~g} \mathrm{~L}^{-1}$, for the first class the grain nature must not be less than $750 \mathrm{~g} \mathrm{~L}^{-1}$; for the second class the grain nature must not be less the $730 \mathrm{~g} \mathrm{~L}^{-1}$, for the third class the grain nature must not be less than $710 \mathrm{~g} \mathrm{~L}^{-1}$, for the fourth class the grain nature must not be less than $700 \mathrm{~g} \mathrm{~L}^{-1}$, for the fifth class this indicator is not limited. The higher the indicator of grain nature the higher amount of nutrition elements can be contained in grain. The glassiness of the studied cultivars exceeds the standard glassiness by this indicator, $60 \%$. These parameters correspond to the demands made to the strong wheat. According to our research the greatest number of starch, $58.6 \%$, was contained in grain of SWW $2 / 127$ cultivar. The starch quantity in grain of Almaly cultivar slightly differed on this indicator and it was $56.1 \%$. According to our research the best cultivar of winter common wheat by the protein quantity was Almaly cultivar. The analysis of the experimental data by gluten quantity in grain demonstrated that both cultivars according to this indicator belong to strong cultivars and Almaly cultivar corresponds to the highest class of the State standard. Quality of gluten and its resilient properties are the major factors determining the baking force of flour. According to the Standard requirements the quality of the wheat gluten of the $1 \mathrm{st}$ and 2nd classes must not be lower than the 1st group (45-75 units of MGD), the quality of the wheat gluten 
of the $3^{\text {rd }}$ and 4 th classes must not be lower than the 2nd group (20-100 units of MGD). The quality of gluten of the studied cultivars of winter common wheat corresponded to the 2 nd group. The negative property of the cultivars, gluten deterioration, was also noted. Gluten was tensile (100 units of MGD).

Thus, at the comparative structure analysis of an ear of the studied cultivars the standard cultivar Almaly differed both by the mass of grain per an ear and by the mass of 1,000 grains, i.e., by the parameters which are the main components of the harvest structure. Having compared the studied cultivars of winter common wheat we noted that the highest productivity was provided by the zoned, domestic cultivar Almaly. At norm of seed sowing in 2 million grains per a hectare and optimum conditions of mineral nutrition with application of $\mathrm{N}_{120} \mathrm{P}_{60}$ this cultivar formed 91.8 centners per 1 hectare. The studied cultivars formed high yield when using surface drip irrigation as harvest accounting had shown. At the total background of mineral nutrition, $\mathrm{N}_{120} \mathrm{P}_{60}$, the studied cultivars formed the grain yield from 77.4 to 101 centners per a hectare. The high rate of productivity at the same time depended both on the norm of seed sowing and on the biological features of the studied cultivars having demonstrated their plasticity.

\section{Conclusion}

The comparative data of indicators of the anatomical structure of a stem, quality of grain, the structural analysis of an ear and productivity of two cultivars of winter common wheat cultivated with use of drip irrigation technology in the conditions of the southeast of Kazakhstan, received as a result of carrying out the researches allowed us drawing the following conclusions:

- SWW 2/127 cultivar at the 3rd internode had bigger indicators of thickness of epidermis, length and width of a large carrying bundle, length and width of xylem, thickness of cells of parenchyma and stem thickness than Almaly cultivar had; but SWW 2/127 cultivar had smaller indicators of thickness of mechanical tissue and primary bark, length and width of small carrying bundles than Almaly cultivar had

- Almaly cultivar had larger total number of small conducting bundles of primary bark than SWW 2/127 cultivar had; and Almaly cultivar had fewer total number of large conducting bundles located in the main tissue than SWW 2/127 cultivar had. Almaly, the standard cultivar, demonstrated high rates of the mass of 1,000 grains $(51.7 \mathrm{~g})$, grain nature $\left(772 \mathrm{~g} \mathrm{~L}^{-1}\right)$, glassiness $(85 \%)$, protein content (15.6\%) and gluten quantity (34.4\%). Almaly cultivar demonstrated higher rates of the structural analysis of a spike in comparison with SWW 2/127 cultivar. Among two studied cultivars at the norm of seed sowing in 2 million grains per a hectare and optimum conditions of mineral nutrition with application of $\mathrm{N}_{120}$ and $\mathrm{P}_{60}$ in combination with drip irrigation, the best yield was demonstrated by Almaly cultivar, 91.8 centners per a hectare

- The plants of the both cultivars of winter common wheat grown up when using the drip irrigation technology had formed the grain nature, the glassiness, the starch content, the protein and the gluten quantity at the level of the State requirements imposed to the strong and valuable wheat, only the gluten quality corresponded to the 2nd group. Drop irrigation positively affected the quality of grain and productivity of two cultivars of winter common wheat ( 77.4 and 101 centners per a hectare) grown on light brown soils in the foothill irrigated zone of the Ile Alatau of the southeast of Kazakhstan

On the basis of the above stated it is possible to conclude that high rates of productivity of two studied cultivars of winter common wheat Almaly and SWW 2/127 were formed under the influence of several factors such as: Anatomic features of a stem; plasticity of the cultivar; the optimally chosen norm of seed sowing and using the drip irrigation technology.

\section{Acknowledgement}

We express our gratitude for help given us when carrying out our researches to the following persons: Ospanbayev Zh.O., the head of the department of the irrigated agriculture of LLP "Kazakh Research Institution of Agriculture and Plant Growing"; Kydyrov A.K., the junior researcher of the department of the irrigated agriculture of LLP "Kazakh Research Institution of Agriculture and Plant Growing"; Kulbekova A.A, the teacher of the Kazakh State Women's Teacher Training University.

\section{Funding Information}

This work was implemented within the scientific project "Development of drip irrigation technology in applying to the main field crops of the irrigated zone of the South and the Southeast of Kazakhstan", UDC 631.1:626.8 (574.51/54), State registration No $0115 R K 02298$. This project was funded by the Ministry of Agriculture of the Republic of Kazakhstan

\section{Author's Contributions}

Zhanar Muratovna Yeraliyeva: Participated in all experiments, coordinated the data-analysis and contributed to the writing of the manuscript.

Meruyert Sakenovna Kurmanbayeva: Designed the research plan and organized the study. 
Karina Khamidovna Makhmudova: Coordinated the data-analysis and contributed to the translating the manuscript.

Tanko Peev Kolev: Designed the research plan and organized the study.

Serik Muktarovich Kenesbayev: Designed the research plan and organized the study.

\section{Ethics}

Data presented in this article haven't been published earlier. People having carried out this research are presented in the list of authors. References to works of other researchers are presented in this article.

\section{References}

Rajaram, S., 2001. Prospects and promise of wheat breeding in the 21st century. Euphytica, 119: 3-15.

U.S. Department of Agriculture, 2005. Statistics and market information system. World Agricultural Production. Foreign Agricultural Service.

FAO, 2011. World wheat, corn and rice. Oklahoma State University, FAOSTAT.

El-Maghraby, M.A., M.E. Moussa, N.S. Hana and H.A. Agrama, 2005. Combining ability under drought stress relative to SSR diversity to common wheat. Euphytica, 141: 301-308.

Martre, P., J.R. Porter, P.D. Jamieson and E. Triboï, 2003. Modeling grain nitrogen accumulation and protein composition to understand the sink/source regulations of nitrogen remobilization for wheat. Plant Physiol., 133: 1959-1967. DOI: 10.1104/pp.103.030585

Metwaly, M.M., 2012. Ecophysiological and anatomical responses of drought stressed wheat plants (Triticum aestivum L.) treating with some bacterial endophytes. PhD Thesis, Kafr-El Sheikh Univ., Kafrelsheikh, Egypt.

Lichtenthaler, H.K., 1996. Vegetation stress: An introduction to the stress concept in plants. J. Plant Physiol., 148: 4-14.

Nonami, H., 1998. Plant water relations and control of cell elongation at low water potentials. J. Plant Res., 111: 373-382.

Patakas, A., N. Nicolaou, E. Zioziou, K. Radoglou and B. Noitsakis, 2002. The role of organic solute and ion accumulation in osmotic adjustment in droughtstressed grapevines. Plant Sci., 163: 361-367.

Mcmaster, G.S., 1997. Phonology, development and growth of wheat (Triticum aestivum L.) shoot apex: A review. Adv. Agronomy, 59: 63-118.

Gupta, N.K., S. Gupta and A. Kumar, 2001. Effect of water stress on physiological attributes and their relationship with growth and yield of wheat cultivars at different stages. J. Agronomy Crop Sci., 186: 55-62.
Dencic, S., R. Kastori, B. Kobiljski and B. Duggan, 2000. Evaporation of grain yield and its components in wheat cultivars and land races under near optimal and drought conditions. Euphytica, 113: 43-52.

Ovchinnikov, A.S. and M.A. Akulinina, 2010. Cucumber drip irrigation in dry steppe zone of Nizhneje Povolzhje light-brown soils. Izvestiya Nizhnevolzhskogo Agrouniversitetskogo Kompleksa.

Tiwari, K.N., A. Singh and P.K. Mal, 2003. Effect of drip irrigation on yield of cabbage (Brassica oleracea L. var. capitata) under mulch and non-mulch conditions. Agricul. Water Manage., 58: 19-28. DOI: $10.1016 / \mathrm{S} 0378-3774(02) 00084-7$

Paul, J.C., J.N. Mishra, P.L. Pradhan and B. Panigrahi, 2013. Effect of drip and surface irrigation on yield, water use-efficiency and economics of capsicum (Capsicum annum L.) Grown under mulch and nonmulch conditions in eastern coastal India. Eur. J. Sustainable Dev., 2: 99-108.

Seyfi, K. and M. Rashidi, 2007. Effect of drip irrigation and plastic mulch on crop yield and yield components of Cantaloupe. Int. J. Agric. Biol.

Phene, C.J., 1995. The sustainability and potential of subsurface drip irrigation. Proceedings of the 5th International Micro Irrigation Congress, American Society of Agricultural Engineers, (IMI' 95), St. Joseph, MI, pp: 359-367,

Yeraliyeva, Z.M., M. Kunelbayev, Z.O. Ospanbayev, M.S. Kurmanbayeva and T.P. Kolev et al., 2016. The study of agricultural techniques of cultivation of new varieties of winter wheat under drip irrigation. Asian J. Microbiol. Biotechnol. Environ. Sci., 18: 779-785.

Nazarbayev, N.A., 2014. The Kazakhstan way-2050: United aim, united interests, united future.

Kharrou, M.H., R. Salah, C. Ahmed, D. Benoit and S. Vincent et al., 2011. Water use efficiency and yield of winter wheat under efferent irrigation regimes in a semi-arid region. Agric. Sci., 2: 273-282.

Hoff, H., 2004. Mainstreaming climate adaption into watershed management climate protection programme for developing countries. Indo-German Bilateral Project Watershed Management.

Abdelraouf, R.E, K.M. Refaie and I.A. Hegab, 2013. Effect of drip lines spacing and adding compost on the yield and irrigation water use efficiency of wheat grown under sandy soil conditions. J. Applied Sci. Res., 9: 1116-1125.

Arafa, Y.E., A.W. Essam and E.M. Hazem, 2009. Maximizing water use efficiency in wheat yields based on drip irrigation systems. Aus. J. Basic Applied Sci., 3: 790-796.

Alam, M., D.H. Rogers and T.J. Dumler, 2009. Subsurface drip irrigation for Alfalfa. Kansas State University.

Suarez-Rey, E., C.Y. Choi, P.M. Waller and D.M. Kopec, 2000. Comparison of subsurface drip irrigation and sprinkler irrigation for Bermuda grass turf in Arizona. Trans. ASAE, 43: 631-640. 
Abd El-Rahman, G., 2009. Water use efficiency of wheat under drip irrigation systems at Al-Maghara area, North Sinai, Egypt. Am. Eurasian J. Agric. Environ. Sci., 5: 664-670.

Camp, C.R., 1998. Subsurface drip irrigation: A review. Trans. ASAE, 41: 1353-1367.

Albaji, M., M. Golabi, V.R. Piroozfar, A. Egdernejad and F.N. Zadeh, 2014. Evaluation of agricultural land resources for irrigation in the ramhormoz plain by using GIS. Agriculturae Conspectus Scientificus.

Zhangaziyev, A.S., 2010. Breeding of winter wheat for disease resistance in the foot hill conditions of Kazakhstan. Proc. Nat. Acad. Sci., 1: 38-39.

Kaurichev, I.S., 1973. Training for Pedology. 1st Edn., Moscow, Kolos, pp: 279.

Frolova, A.A. and M.E. Atselovich, 1965. Agrochemical Methods of Analysis of Soils. 1st Edn., Moscow, pp: 436.

Permyakov, A.I., 1988. Microtechnics. Moscow.

Prozina, M.N., 1960. Botanical Microtechnics, 1st Edn., Moscow, pp: 208.

Lakin, G.F., 1990. Biometry. 1st Edit., Moscow, pp: 352.

GOST, 2017a. 10842-89 Grain of cereals and bean crops and seeds of oil-bearing crops. Method of Determination of Mass of 1,000 grains or 1,000 seeds.

GOST, 2017b. 10840-64 Grain methods of nature determination.

GOST, 2017c. 10987-76 Grain methods of glassiness determination.

GOST, 2017d. 13586.5-93 Grain method of humidity determination.

GOST, 2017e. 10846-91 Grain and products of its processing. Method Protein Determination.
GOST, 2017f. 10845-98 Grain and products of its processing. Method Starch Determination.

GOST, 13586g. 1-68, 2017. Grain methods of determination of quantity and quality of gluten in wheat.

Dospekhov, B.A., 1985. Technique of field experiment (with bases of statistical processing of results of researches). Moscow.

Lazarevich, C.B, 1999. The evolution of wheat stem anatomy. Minsk.

Wallace, L.E. and F.H. McNeal, 1966. Stem Sawflies of Economic Importance in Grain Crops in the United States. 1st Edn., Agricultural Research Service, Washington, DC. pp: 50.

Travis, A.J., S.D. Murison, D.J. Hirst, K.C. Walker and A. Chesson, 1996. Comparison of the anatomy and degradability of straw from varieties of wheat and barley that differ in susceptibility to lodging. J. Agric. Sci., 127: 1-10. DOI: 10.1017/S0021859600077327

Batoyev, B.B., 1991. Anatomical and morphological features of winter wheat cultivars of various productivity. Candidate of agricultural sciences. Ph.D. Thesis, Timiryazev Agricultural Academy, Moscow.

SSRK, 2017. State standard of the republic of Kazakhstan.

Zharikova, G.G., 2005. Microbiology of food products, sanitation and hygiene. Moscow.

Kazakov, E.D. and G.P. Karpilenko, 2005. Biochemistry of grain and grain products. Saint Petersburg.

Koehler, P. and H. Wieser, 2013. Chemistry of Cereal Grains. In: Handbook on Sourdough Biotechnology, Gobetti, M. and M. Gänzle, (Eds.), Springer Science and Business Media, New York, ISBN-10: 1461454255, pp: 11-45. 